\title{
UPF0606 Protein KIAA1549
}

National Cancer Institute

\section{Source}

National Cancer Institute. UPF0606 Protein KIAA1549. NCI Thesaurus. Code C98019.

UPF0606 protein KIAA1549 (1950 aa, 211 kDa) is encoded by the human KIAA1549

gene. This protein may play a role in brain functions. 